\title{
Lesson Study For Learning Community Dalam Model Pembelajaran Motoric
}

(Implementasi dalam Materi Sains SMP Berdasarkan Kurikulum 2013)

\section{Wayan Sukarjita 1), Fakhruddin 2), Yusniati M Yusuf, 3) Maria Y. Giri4)}

1,2,3) Dosen Program Studi Pendidikan Fisika, FKIP Undana

4) Guru Sains SMP N 13 Kupang

*I Wayan Sukarjita, Dosen Program Studi Pendidikan Fisika, FKIP Undana;

Email:

wayansukarjita@yahoo.co.id
Abstract: This article analyzes the implementation of Science learning in the Lesson Study for Learning Community (LSLC) setting by applying MOTORIC learning models. The purpose is to analyze and describe the impact of the application of LSLC in MOTORIC learning models on improving the quality of the Science learning process. MOTORIC is a learning model consisting of 7 learning stages, namely Motivation, Observation, Talking, Orientation, Reflection, Implementation and Confirmation.

The implementation of MOTORIC model in the learning process is carried out in the Lesson Study for Learning Community (LSLC) settings: Plan, Do and See. Open lesson was carried out on Science subjects of grade VII students on SMP 13 Kupang as one of the partner schools in the development of LSLC in Kupang City which implemented the 2013 Curriculum. The model teacher was Mrs. Maria Giri, S.Pd, one of Science teachers on SMP N 13 Kupang.

Based on the results of observation and analysis, it can be concluded that the application of LSLC in MOTORIC learning models have to provides opportunities for the students to learn together with their peers, and the application of LSLC in the MOTORIC learning model has a positive impact to increasing the active role of the students in the learning process by $53.49 \%$ in the very active category and by $30.93 \%$ categorized as quite active.

Keywords: LSLC, learning models, MOTORIC, Science

\begin{abstract}
Abstrak: Artikel ini memuat analisis pelaksanaan pembelajaran Sains dalam setting Lesson Study for Learning Community (LSLC) dengan menerapkan model pembelajaran MOTORIC. Tujuannya adalah untuk menganalisis dan mendeskripsikan dampak penerapan LSLC dalam pembelajaran model MOTORIC terhadap peningkatan kualitas proses belajar Sains. MOTORIC adalah sebuah model pembelajaran yang terdiri dari 7 tahapan pembelajaran yaitu Motivation, Observation, Talking, Orientation, Reflection, Implementation dan Confirmation.

Implementasi model MOTORIC dalam pembelajaran dilakukan dalam setting Lesson Study for Learning Community (LSLC) dengan tahapan plan, do dan see. Open lesson dilakukan pada mata pelajaran Sains siswa kelas VII SMPN 13 Kupang sebagai salah satu sekolah mitra dalam pengembangan LSLC di Kota Kupang yang menerapkan Kurikulum Tahun 2013. Guru modelnya adalah ibu Maria Y. Giri, S.Pd salah satu guru Sains SMP N 13 Kupang.

Berdasarkan hasil observasi dan analisis, maka dapat disimpulkan bahwa implementasi model pembelajaran MOTORIC dalam setting LSLC efektif untuk meningkatkan kualitas proses pembelajaran Sains sebagaimana yang diharapkan oleh konsep LSLC, yakni semua siswa berhak untuk belajar, siswa belajar kolaboratif dan menyenangkan, antara siswa saling mendukung untuk berkembang sesuai potensi yang dimiliki masing-masing siswa. Aktivitas siswa pada akhir siklus menunjukkan sebanyak $53.49 \%$ berada dalam kategori sangat aktif dan terkategori cukup aktif sebesar $30.93 \%$.
\end{abstract}

Kata Kunci: LSLC, model pembelajaran, MOTORIC, Sains 


\section{Pendahuluan}

Sekolah merupakan salah satu pusat pendidikan bagi anak. Tugas utamanya adalah menyelenggarakan pendidikan dan pembelajaran, untuk menghasilkan calon-calon sumber daya manusia yang berkualitas. Dalam mengantisipasi perkembangan ilmu pengetahuan, teknologi, seni dan informasi yang sangat pesat, mendorong dunia pendidikan harus berpartisipasi aktif dalam mem $\square$ bina, mengembangkan, dan mengelolanya secara manageble, kontinyu dan berkesinambungan. Dengan adanya pembinaan secara kontinyu, berkesinambungan dan terencana diharapkan menghasilkan sumberdaya yang lebih dapat bermutu yang terstandar (quality assurance), dapat dipertanggung jawabkan (accountable) baik secara internal maupun eksternal.

Untuk menghadapi tuntutan tersebut, salah satu upaya yang dapat dilakukan adalah meningkatkan mutu dan pengelolaan proses belajarmengajar secara sistemik dan sistematis. Hal ini perlu dilakukan karena memang tugas utama sekolah adalah melaksanakan proses pembelajaran dan pendidikan. Peningkatan mutu dan pengelolaan proses pembelajaran dan pendidikan sistemik dan sistematis, yang dimaksudkan adalah bahwa pengelolaan proses pembelajaran tidak dipandang sebagai suatu hal yang berdiri sendiri, namun ia merupakan bagian integral dari kegiatan lainnya, dilaksanakan secara runtut sejak dari input, proses, output, sampai pada out come.

Oleh karena itu, sudah sepatutnya bila seluruh komponen yang ada baik guru, siswa maupun komunitas sekolah pada akhirnya harus bermuara pada peningkatan proses dan hasil pembelajaran. Selain itu, proses pembelajaran juga dipandang sebagai suatu proses transformasi, pembentukan karakter dan keterampilan sehingga para peserta didik memiliki kompetensi yang terstandar sesuai dengan kebutuhan pasar, bermutu yang dapat di pertanggung jawabkan.

Banyak faktor yang berpengaruh dalam upaya meningkatkan mutu proses dan hasil pembelajaran. Salah satunya adalah keberhasilan dalam proses pembelajaran di kelas. Proses pembelajaran dikatakan berhasil apabila transfer informasi dari guru ke siswa berlangsung secara efektif, inovatif, menyeluruh dan menyenangkan.

Menyeluruh dan menyenangkan dalam arti bahwa dalam proses pembelajaran, siswa merasa merupakan bagian dari proses pembelajaran dan terlibat langsung dalam proses pembelajaran. Hal ini membutuhkan kreativitas dan inovasi guru untuk memotivasi dan mengkondisikan siswa agar aktif dan terlibat dalam proses pembelejaran. Satu hal yang tidak kalah pentingnya adalah, perlunya suasana pembelajaran yang memanfaatkan teman sebaya sebagai tutor dalam proses pembelajaran.

Berkaitan dengan terciptanya suasana belajar seperti tersebut, telah dilaksanakan kegiatan pembelajaran dalam bentuk Lesson Study untuk menumbuhkan rasa kebersamaan belajar siswa dalam sebuah komunitas belajar (Learning Community). Implementasi Lesson Study for Learning Community (LSLC) ini dilaksanakan pada materi Sains SMP kelas VII Kurikulum 2013 dengan menerapkan model pembelajaran MOTORIC (Motivation, Orsebation, Talking, Orientation, Reinforcement, Implementation and Confirmation) di SMP N 13 Kupang.

Salah satu tujuan kegiatan LSLC ini ini adalah untuk laksanakan proses pembelajaran yang berorientasi pada aktivitas siswa dan bukan pada guru serta menerapkan model pembelajaran yang efektif, kolaboratif dan inovatif untuk meningkatkan motivasi dan partisipasi siswa dalam proses pembelajaran.

Istilah Lesson Study lahir dalam sistem pendidikan di Jepang dari bahasa Jepang Jugyokenkyu. Cikal bakal kegiatan semacam ini mulai dilakukan di Jepang pada era Tahun 1870-an. Akhirnya kini Lesson Study berkembang dengan berbagai variasinya di berbagai negara, termasuk di Indonesia. Di Indonesia, Lesson Study baru dikenalkan oleh para ahli pendidikan Jepang pada sekitar Tahun 2004 melalui Program Kerjasama Teknis dengan JICA.

Lesson Study merupakan suatu bentuk pembinaan profesi pendidik melalui pengkajian pembelajaran secara kolaboratif dan berkelanjutan berlandaskan prinsip kolegalitas dan mutual learning untuk membangun learning community, jadi Lesson Study for Learning Community (LSLC). 
Jadi Lesson Study bukanlah metode atau model pembelajaran untuk siswa ataun mahasiswa, melainkan sebuah bentuk pembinaan untuk mengembangkan kemampuan guru secara kolaboratif guna memperbaiki kualitas pembelajaran/pendidikan. Lesson Study yang berkembang dan dilaksanakan di Indonesia ada tiga tahap, yaitu Plan (merencanakan), Do (melaksanakan), dan See (merefleksikan) yang dilaksanakan secara bersiklus dan berkelanjutan.

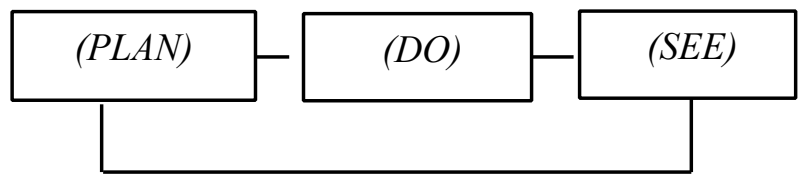

Gambar 1: Siklus Lesson Study (Saito, et. 2005)

Ketiga tahapan Lesson Study ini ada kesesuaian dengan tahapan Penelitian Tindakan Kelas (PTK). Oleh karena itu jika tahapan Lesson Study ini digabungkan atau diadopsi dalam pelaksanaan tahapan PTK maka dapat diperoleh hasil yang lebih maksimal.

Awalnya ketika diperkenalkan di Indonesia, Lesson Study dilaksanakan oleh guru-guru di MGMP MIPA di SMP dan di SMA. Selain diterapkan di MGMP, kini Lesson Study juga dilaksanakan oleh guru-guru di sekolah atau yang dikenal dengan istilah Lesson Study Berbasis Sekolah (LSBS).

Mengapa Lesson Study yang dipilih sebagai salah satu alternatif? Lesson Study merupakan suatu cara efektif yang dapat meningkatkan kualitas mengajar guru dan aktivitas belajar siswa. Hal ini karena: a) pengembangan Lesson Study dilakukan dan didasarkan pada hasil "sharing" pengetahuan profesional yang berlandaskan pada praktek dan hasil pengajaran yang dilaksanakan para guru; b) penekanan mendasar Lesson Study adalah para siswa terutama terkait kualitas belajar; c) tujuan pelajaran dijadikan fokus dan titik perhatian utama dalam pembelajaran di kelas; d) berdasarkan pengalaman riil di kelas, Lesson Study mampu menjadi landasan bagi pengembangan pembelajaran; dan e) Lesson Study akan menempatkan peran para guru sebagai peneliti pembelajaran (Lewis, 2002).

Selain itu Lesson Study yang didisain dengan baik akan menghasilkan guru yang profesional dan inovatif. Dengan melaksanakan Lesson Study para guru dapat: a) menentukan tujuan pelajaran (lesson), satuan (unit) pelajaran, metode pelajaran yang efektif; b) mengkaji dan meningkatkan pelajaran yang bermanfaat bagi siswa; c) memperdalam pengetahuan tentang mata pelajaran yang disajikan para guru; d) menentukan tujuan jangka panjang yang akan dicapai para siswa; e) merencanakan pembelajaran secara kolaboratif; f) mengkaji secara teliti belajar dan perilaku siswa; g) mengembangkan pengetahuan pembelajaran yang dapat diandalkan; dan h) melakukan refleksi terhadap pembelajaran yang dilaksanakan berdasarkan pandangan siswa dan koleganya (Lewis, 2002).

Lesson Study dapat dilaksanakan oleh para guru secara kolaboratif dan berkelanjutan baik di tingkat MGMP ataupun di sekolah bahkan di LPTK jika dilandasi oleh dukungan sebagai berikut: 1) Semangat mengkritik diri sendiri (hansei); 2) Keterbukaan terhadap masukan dari orang lain; 3) Mau mengakui kekurangan, dan mau menerima saran orang lain; 4) Mau memberi masukan yang jujur dan penuh respek.

Dalam perkembangannya, kini sekolahsekolah di Jepang mengembangkam sebuah komunitas belajar (Learning Community) dimana siswa, guru, orang tua dan seluruh penggiat pendidikan saling belajar. Filosofi Learning Community (LC) yang kini sedang berkembang di Jepang adalah guru bukan mengajar tapi belajar. Selain itu, LC mengandung konsep bahwa siswa tidak dibiarkan sendiri dan tidak seorang pun siswa yang terabaikan, belajar kolaboratif dan siswa nyaman belajar.

Untuk menciptakan suasana belajar yang nyaman sebagaimana konsep LC maka dapat dikondisikan melalui implementasi Lesson Study. Sehingga, bentuk pembelajaran kolaboratif melalui implementasi Lesson Study berdasarkan aspekaspek kolegatlitas untuk menciptakan suasana pembelajaran yang menyenangkan dalam sebuah sebuah komunitas belajar (Learning Community) kini di sebut Lesson Study for Learning Community (LSLC). LSLC inilah yang kini sedang berkembang dan di laksanakan sekolah-sekolah di Jepang.

\section{Metodologi Penelitian}

Penerapan Lesson Study for Learning Community (LSLC) dalam proses pembelajaran Sains SMP kelas VII ini dilaksanakan di SMP Negeri 13 Kupang dengan menerapkan model 
pembelajaran MOTORIC. Pelaksanaan Plan, Do dan See dalam model MOTORIC ini meliputi beberapa tahapan kegiatan dengan rancangan sebagai berikut.

\section{Tabel 1. Tahap Rancangan dan Metode Pelaksanaan LSLC Materi Sains SMP Kelas VII}

\begin{tabular}{|l|l|}
\hline Tahapan & \multicolumn{1}{|c|}{ Aktivitas } \\
\hline Tahap 1 & $\begin{array}{l}\text { Pemilihan topik atau materi pembelajaran } \\
\text { untuk kegiatan lesson study }\end{array}$ \\
\hline Tahap 2 & $\begin{array}{l}\text { Merancang dan menyusun desain } \\
\text { pembelajaran }\end{array}$ \\
\hline Tahap 3 & $\begin{array}{l}\text { Mendiskusikan desain pembelajaran yang } \\
\text { telah disusun dengan guru lain sebagai } \\
\text { anggota kelompok lesson study IPA }\end{array}$ \\
\hline Tahap 4 & $\begin{array}{l}\text { Merivisi dan menyempurnakan desain } \\
\text { pembelajaran sesuai saran dan masukan dari } \\
\text { anggota kelompok lesson study IPA. }\end{array}$ \\
\hline Tahap 5 & $\begin{array}{l}\text { Guru model melaksanakan pembelajaran } \\
\text { dengan model MOTORIC dalam bentuk } \\
\text { LSLC, yakni siswa duduk secara } \\
\text { berkelompok (heterogen) dengan beberapa } \\
\text { kelompok diamati oleh dua orang guru IPA } \\
\text { yang bertindak selaku } \text { observer. }\end{array}$ \\
\hline Tahap 6 & $\begin{array}{l}\text { Setelah proses pembelajaran LSLC, } \\
\text { dilaksanakan refleksi. Guru } \text { observer } \\
\text { menyampaikan hasil pengamatan terhadap } \\
\text { aktivitas siswa selama guru model } \\
\text { memberikan materi pelajaran. } \\
\text { Segala kekurangan yang ada menjadikan } \\
\text { tonggak awal bagi guru model untuk } \\
\text { memperbaiki aktivitas pembelajaran pada } \\
\text { pertemuan berikutnya. }\end{array}$ \\
\hline
\end{tabular}

Pelaksanaan LSLC untuk mata pelajaran Sains Kelas VII SMP ini meliputi 3 langkah kegiatan. Langkah-langkah tersebut meliputi:

\section{a. Perencanaan (Plan)}

Tahap awal dari plan adalah guru model mendesain materi dan model pembelajaran yang akan dilaksanakan. Selain materi pembelajaran, dirancang pula Rencana Pelaksanaan Pembelajaran (RPP), Lembar Kerja Peserta Didik (LKPD) dan media pembelajaran. Hasil desain pembelajaran ini kemudian disempurnakan berdasarkan saran hasil diskusi dengan guru lain anggota pelaksanaan Lesson Study.

\section{b. Implementasi dan Observasi (Do)}

Pada tahap ini, guru model mengimplementasikan desain pembelajaran yang telah disusun dalam bentuk tindakan (do) pembelajaran. Posisi siswa diatur secara berkelompok (heterogen).

Saat guru model menyampaikan materi pelajaran, observer melakukan pengamatan terhadap aktivitas siswa selama proses pembelajaran berlangsung. Setiap aktivitas siswa baik secara individual maupun kelompok diamati dan direkam oleh observer dengan menggunakan format observasi yang telah disediakan.

\section{c. Refleksi (See)}

Kegiatan ini dilaksanakan setelah seluruh kegiatan pembelajaran selesai dilaksanakan. Berdasarkan hasil obeservasi yang telah direkam oleh observer saat proses pembelajaran berlangsung, dilaksanakanlah refleksi dengan salah satu dari observer menjadi moderator dan seorang lagi menjadi notulen.

Masing-masing observer menyampaikan hasil pengamatannya dan sekaligus memberikan saran perbaikan jika dijumpai hal-hal yang dianggap menjadi keganjilan selama proses kolaborasi antar siswa selama pembelajaran berlangsung. Demikian pula, observer dapat memberikan saran perbaikan kepada guru model agar aktivitas pembelajaran semakin menyenangkan.

\section{Hasil dan Pembahasan}

Penerapan LSLC dengan model pembelajaran MOTORIC pada pelajaran Sains SMP kelas VII yang meliputi tiga tahap yakni perencanaan pelaksanaan pembelajaran (Plan), implementasi dan observasi pembelajaran (Do) dan refleksi (See) berdampak pada meningkatnya peran serta siswa dalam proses pembelajaran.

Hasil yang diperoleh pada tahap pertama LSLC melalui kegiatan refleksi menunjukkan bahwa jumlah siswa dalam tiap kelompok masih banyak, heterogenitas kelompok masih kurang, dan kerjasama antar siswa dalam satu kelompok masih rendah.

Selain itu, beberapa siswa belum terlibat aktif dalam proses pembelajaran dan justru mengutamakan menyalin pekerjaan temannya sehingga tidak mampu memahami materi pembelajaran dengan baik. Hal ini menunjukkan bahwa motivasi belajar beberapa siswa masih rendah. Dalam kegiatan tahap pertama ini juga terlihat bahwa alokasi waktu pada saat diskusi 
kelompok belum tepat, dan waktu setiap sesi kegiatan belum terkontrol dengan baik.

Refleksi yang dilakukan pada tahap kedua dari kegiatan LSLC ini memperlihatkan bahwa jumlah siswa dalam tiap kelompok sudah sesuai, heterogenitas kelompok cukup baik, dan kerjasama antar siswa dalam satu kelompok telah meningkat. Jumlah siswa yang terlibat aktif dalam proses pembelajaran semakin meningkat meskipun masih terdapat beberapa siswa yang belum mampuh memahami materi pelajaran secara menyeluruh.

Hal ini berarti bahwa aktivitas dan motivasi belajar siswa dalam proses pembelajaran sudah semakin baik. Sedangkan alokasi waktu pada saat diskusi kelompok telah sesuai, dan waktu setiap sesi kegiatan cukup terkontrol. Dari keseluruhan hasil yang terlihat pada tahap kedua ini disarankan untuk menyesuaikan waktu untuk fase Talking pada penerapan model MOTORIC. Fase ini membutuhkan waktu yang cukup lama bagi siswa, sehingga mengurangi waktu untuk fase lain dalam pembelajaran MOTORIC.

Tahap ketiga dari kegiatan LSLC ini semakin memperlihatkan kerjasama antar siswa dalam satu kelompok semakin baik. Hampir semua siswa terlibat aktif dalam proses pembelajaran. Namun, jumping task belum nampak dalam pembelajaran. Selain itu, tampak pula efektivitas kerjasama antar siswa dalam satu kelompok. Hampir semua siswa telah terlibat aktif dalam proses pembelajaran.

Berdasarkan hasil yang telah diperoleh di atas, dapatlah dijelaskan bahwa penerapan kegiatan lesson study yang meliputi perencanaan pelaksanaan pembelajaran (plan), implementasi dan observasi pembelajaran (do) dan refleksi (see) dalam mata pelajaran Sains Kelas VII SMP memberikan dampak positip dalam upaya menciptakan suasana kelas yang kondusif serta menyenangkan bagi siswa.

Selain bermanfaat bagi usaha peningkatan keaktifan siswa dalam proses pembelajaran, pelaksanaan lesson study for learning community ini berdampak pula bagi guru model ataupun guru IPA lain. Keterbukaan, kolaboratif dan kerjasama antar guru dalam merancang desain pembelajaran belum pernah terjadi sebelum pelaksanaan Lesson Study.

Pelaksanaan LSLC juga berdampak pada kualitas desain pembelajaran yang lebih baik karena merupakan hasil kolaborasi buah pikiran dari beberapa orang guru yang terlibat dalam pelaksanaan lesson study for learning community.

Demikian pula, dengan adanya kegiatan plan dan see yang melibatkan beberapa orang guru, membawa nuansa proses pembelajaran yang semakin akrab dan menyenangkan.

\section{Dampak Penerapan LSLC pada Suasana Belajar Siswa}

Hasil penelitian menunjukkan bahwa penerapan LSLC dalam model pembelajaran MOTORIC dapat memperbaiki pola siswa dalam belajar di kelas. Jika pada awalnya siswa senantiasa dijejali oleh kegiatan catat mencatat, kini aktivitas siswa baik secara individu maupun kelompok sudah mulai nampak. Hal ini diindikasikan oleh tingkat keaktifan siswa dari siklus I, II dan III yang semakin meningkat. Keaktifan siswa untuk terlibat dalam proses pembelajaran dikelas dirangsang oleh terciptanya suasana pembelajaran yang menyenangkan, bersahabat dan bersifat kolaboratid dengan teman sebaya.

Selain itu, tahapan implementation pada fase model MOTORIC yang mengharuskan siswa dalam kelompok mencari secara mandiri konsepkonsep yang berkaitan aplikasi kehidupan seharihari. Perubahan sikap, keaktifan dan pola belajar siswa dalam belajar dikelas dengan menerapkan LSLC dengan model MOTORIC semakin lama semakin baik

Hasil analisa data menunjukkan bahwa pada siklus I, sebagian besar siswa $(45,7 \%)$ masih kurang aktif dalam mengikuti pola proses pembelajaran. Hanya sebagian kecil yaitu 5,1\% siswa yang tergolong sangat aktif dan 9,8\% siswa yang berada dalam kategori terlibat aktif dalam proses pembelajaran. Hal ini sejalan dengan hasil refleksi pada siklus I yang sebagian besar siswa mengindikasikan masih belum terbiasa dengan model MOTORIC yang diterapkan berbasis LSLC, karena lebih menekankan pada keaktifan siswa dalam menemukan konsep.

Pada siklus II, siswa sudah mulai terbiasa dalam pembelajaran MOTORIC berbasis LSLC, akan tetapi keaktifan siswa secara umum masih belum optimal. Pada siklus II ini, jumlah siswa yang aktif sudah meningkat yaitu sebesar 12,6\% dan kelas didominasi oleh siswa dalam kategori cukup aktif yaitu sebesar 39,1 \%. Sedangkan jumlah siswa yang berada dalam kategori kurang 
aktif dalam mengikuti proses pembelajaran di kelas masih cukup besar yakni sebesar 33,6 \%.

Refleksi dan perbaikan pada siklus II ternyata berdampak besar pada pola dan aktifitas belajar siswa dalam proses pembelajaran. Pada siklus III ini, penerapan model MOTORIC berbasis LSLC sudah mulai berdampak positif terhadap suasana proses pembelajaran. Fase Talking yang pada siklus sebelumnya tidak terarah dengan baik, kini pada siklus ketiga sudah berjalan dengan baik. Demikian pula, fase Reinforcement pada model MOTORIC sudah melibatkan siswa, yang sebelumnya fase reinforcement ini terlalu didominasi oleh guru. Siswa dalam kelompoknya sudah mulai terbiasa untuk menemukan sendiri serta mencari contoh konsep yang sepadan dalam fase reinforcement. Keaktifan siswa pada siklus III ini didominasi oleh kategori aktif $(43,3 \%)$ dan jumlah siswa yang kurang aktif menurun hingga $12,3 \%$

Secara lengkap perubahan pola belajar, sikap dan aktifitas keterlibatan siswa dalam proses pembelajaran sebagaimana terurai pada Tabel.2 berikut.

\section{Tabel 2. Prosentase Keaktifan Siswa dalamProses Pembelajaran di Kelas}

Kategori Keaktifan Siswa di Kelas (dalam \%)

Siklus

\begin{tabular}{llllll} 
& $\begin{array}{l}\text { Sangat } \\
\text { Aktif }\end{array}$ & Aktif & $\begin{array}{l}\text { Cukup } \\
\text { Aktif }\end{array}$ & $\begin{array}{l}\text { Kurang } \\
\text { Aktif }\end{array}$ & $\begin{array}{l}\text { Tidak } \\
\text { Aktif }\end{array}$ \\
\hline Siklus I & 5,1 & 9,8 & 26,5 & 45,7 & 12.9 \\
Siklus II & 10,2 & 12,6 & 39,1 & 33,6 & 4.5 \\
Siklus III & 15,6 & 43,3 & 26,8 & 12.3 & 2.0 \\
\hline
\end{tabular}

Bergesernya kategori tingkat keaktifan siswa dari siklus I yang didominasi siswa tidak aktif bergeser ke pola kelas pembelajaran yang lebih aktif pada siklus II dan siklus III secara jelas tampak pada Gambar 2 berikut.

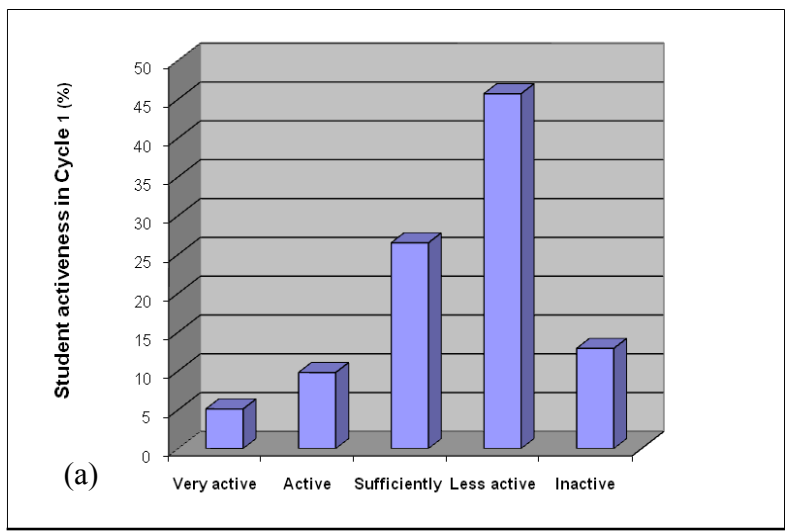

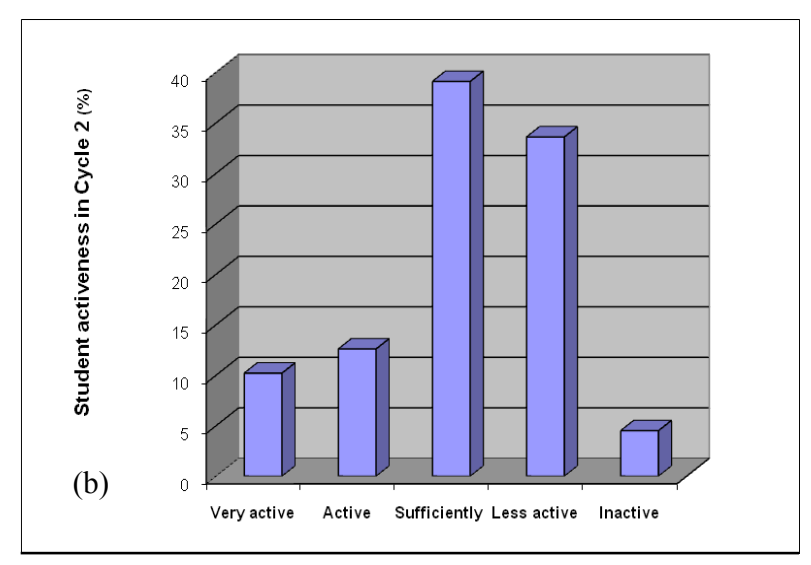

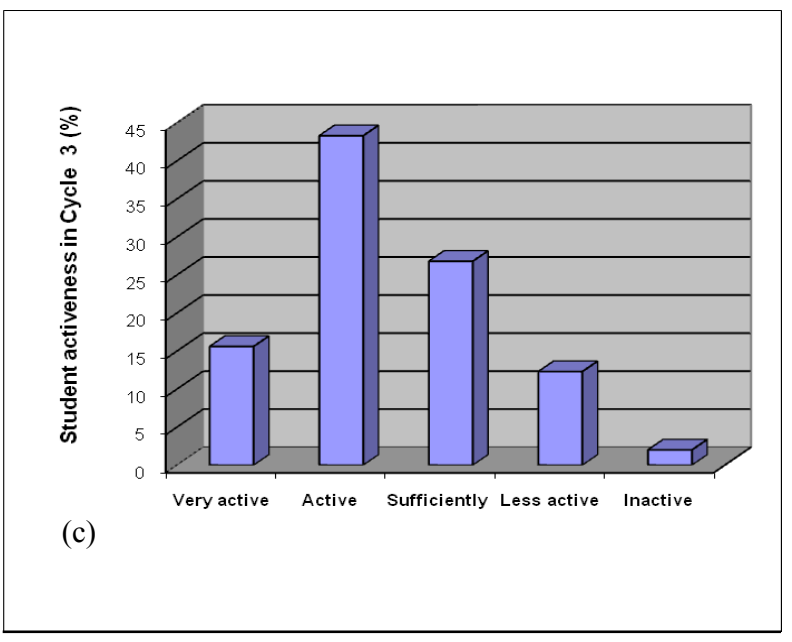

Gambar 3. Perkembangan Keaktifan Siswa pada Siklus I, II dan Siklus III.

Hasil implementasi menunjukkan bahwa penerapan model pembelajaran MOTORIC dalam setting LSLC memberikan pengalaman baru bagi siswa dalam proses pembelajaran. Walaupun tidak seluruhnya, namun sebagian besar siswa menunjukkan antusiasme yang tinggi untuk saling belajar dengan teman sebayanya. Hubungan saling belajar dengan rasa senang antara siswa sangat nampak pada pembelajaran ketika pembelajaran mulai masuk pada fase Observation, sementara itu kegiatan saling belajar dalam kelompok kecil pada pembelajaran mulai tumbuh ketika siswa berada pada fase Talking. Dominasi guru dalam pembelajaran sedikit muncul ketika pembelajaran pada fase Orientation dan Reflection dimana guru 
mengarahkan dan memberikan penekanan konsep yang benar ketika ada kekeliruan konsep yang muncul pada fase Talking. Fase Implementation dan Confirmation dalam model MOTORIC memberikan tantangan bagi siswa dalam proses pembelajaran. Pada fase ini siswa mulai dihadapkan pada penerapan materi pelajaran dalam kehidupan nyata dalam bentuk soal sharing ataupun tugas berupa soal jumping. Pada fase ini siswa akan didorong untuk mencoba memecahkan permasalahan dengan level yang lebih tinggi untuk meningkatkan kemampuan mereka. Pada fase ini, guru dapat pula menyisipkan aspek pengembangan sikap dan karakter sesuai materi Sains yang diajarkan.

Berdasarkan uraian dan hasil analisis di atas, maka dapat dikatakan bahwa penerapan LSLC dalam pelajaran Sains Kelas VII SMP efektif meningkatkan motivasi dan keaktifan belajar siswa.

\section{Kesimpulan}

Berdasarkan hasil penerapan LSLC pada mata pelajaran Sains SMP, maka dapat disimpulkan beberapa hal, antara lain:

Penerapan LSLC dalam model pembelajaran MOTORIC memberikan warna dan nuansa baru yang lebih terbuka, kolaboratif dan menyenangkan dalam pengelolaan proses pembelajaran di kelas.

Penerapan LSLC dalam model pembelajaran MOTORIC berdampak positif pada meningkatnya peran aktif siswa dalam proses pembelajaran.

Penerapan LSLC dalam model pembelajaran MOTORIC memberikan kesempatan kepada guru Sains untuk bekerja sama dalam merancang dan mengimplementasikan skenario pembelajaran secara bersama.

Penerapan LSLC dalam model pembelajaran MOTORIC memberikan ruang dan waktu yang lebih luas bagi siswa untuk belajar bersama serta lebih aktif dengan teman sebaya di bawah koordinasi dan fasiltasi guru.

Penerapan LSLC dalam model pembelajaran MOTORIC secara efektif dapat meningkatkan kualitas proses pembelajaran Sains SMP.

\section{Daftar Pustaka}

Anggara, Rian. 2012. Penerapan Lesson Study Berbasis Musyawarah Guru Mata Pelajaran (MGMP) terhadap Peningkatan Kompetensi Profesional Guru PKn SMP Se Kabupaten Ogan Ilir. (online): http://eprints.unsri.ac.id/142.

Cerbin, William and Bryan Kopp. 2006. Lesson Study as a Model for Building Pedagogical Knowledge and Improving Teaching. In International Journal of Teaching and Learning in Higher Education 2006 (online), Vol 18, Number 3, 250-257. Available: http://www.isetl.org/ijtlhe/ISSN 1812 - 9129.

Direktoral Jenderal Pendidikan Tinggi, Depdikbud. 2009. Panduan untuk Lesson Study Berbasis MGMP dan Lesson Study Berbasis Sekolah. Jakarta: Pelita.

Direktorat Ketenagaan DIKTI. 2010. Program Perluasan Lesson Study untuk Penguatan LPTK (Lesson Study Dissemination Program for Strengthening Teacher Education in Indonesia), Jakarta: Direktorat Ketenagaan Dikti, Depdiknas.

Fernandez, Clea. 2002. Learning from Japanese Approaches to Professional Development: The Case of Lesson Study. Journal of Teacher Education 2002; 53; 393. DOI: 10.1177/002248702237394.

Herawati, 2009, Lesson Study Berbasis Sekolah, Malang: Bayumedia Publishing.

http://pps.uny.ac.id/berita/lesson-study-learningcommunity-best-practice-pendidikan-dijepang.html, diakses 23 Oktober 2016.

Istamar, S. 2008. Lesson Study, FMIPA UM. Malang.

John Elliott. 2016. Significant themes in developing the theory and practice of lesson study. International Journal for Lesson and Learning Studies, Vol. 5 Iss: 4, pp.274280.

Lukitasari, Marheny, et al.2014. Lesson Study in Improving the Role of E-Portfolio on the Metacognitive Skill and Concept Comprehension: A Study on Cell Biology Subject in IKIP PGRI Madiun, Indonesia." American Journal of Educational Research 2.10 (2014): 919-924.

Subadi, Pramujiyanti, at al. 2013. A Lesson Study as a Development Model of Professional Teachers. International Journal of 
Education. ISSN 1948-5476 2013, Vol. 5, No. 2

Sukarjita, I.W. 2015. Model Pembeajaran MOTORIC, PMIPA Press.

Supriatna, Asep, dkk. 2010. Implementasi Lesson Study. Bandung: Rizqi Press.

Ulla Runesson, 2016. Pedagogical and learning theories in lesson and learning studies revisited. International Journal for Lesson and Learning Studies, Vol. 5 Iss: 4, pp.295 $-299$

Undang, G. 2009. Lesson Study Model Pengkajian Pembelajaran Kolaboratif. Bandung: Sayagatama Pers.

William Cerbin and Bryan Kopp. 2006. Lesson Study as a Model for Building Pedagogical Knowledge and Improving Teaching. International Journal of Teaching and Learning in Higher Education. 2006, Volume 18, Number 3, 250-257, ISSN 1812-9129. 